\title{
An Eco-Friendly Synthesis of Heterocyclic Moieties Condensed with Pyrazole System under Green Conditions and Their Biological Activity
}

\author{
Mohamed A. El-Borai", Hala F. Rizk, Mohamed R. Sadek, Mai M. El-Keiy \\ Department of Chemistry, Faculty of Science, Tanta University, Tanta, Egypt \\ Email: "m_elborai@yahoo.com
}

Received 8 March 2016; accepted 8 May 2016; published 11 May 2016

Copyright @ 2016 by authors and Scientific Research Publishing Inc. This work is licensed under the Creative Commons Attribution International License (CC BY). http://creativecommons.org/licenses/by/4.0/

CC) (i) Open Access

\begin{abstract}
The efficient, facile and green synthesis of 4-bromo pyrazolone by using $\mathrm{N}$-bromo saccharine as valuable green reagent encouraged us to prepare some new fused heterocycles as furopyrazole, pyranopyrazole, imidazopyrazole, pyrazolothiazole, pyrazol thiazolopyrimidine, pyrazolothiazine, oxathinopyrazole, pyrazolobenzooxazine, and pyrazoloquinoxaline. The synthesis was carried out by a basic condensation of bromo pyrazolone 2 and a suitable reagent in a one-pot reaction using chitosan as a green basic catalyst. The reactions were carried out by microwave irradiation technique as a green source of energy as well as the conventional heating. The antioxidant activity of the prepared compounds was studied using 1,1-phenyl-2-picrylhydrazyl (DPPH) assay and their antibacterial activity against Gram-positive, Gram-negative bacteria and antifungal activity was evaluated.
\end{abstract}

Keywords

4-Bromo Pyrazolone, N-Bromo Saccharine, Chitosan, Microwave Irradiation, DPPH

\section{Introduction}

The goals of green chemistry are to reduce and prohibit the pollution of nature, ensure perpetual life on earth and minimize the use and production of hazardous materials [1]-[3].

The chemistry of pyrazole system has attracted much attention and many methods for synthesis have been "Corresponding author.

How to cite this paper: El-Borai, M.A., Rizk, H.F., Sadek, M.R. and El-Keiy, M.M. (2016) An Eco-Friendly Synthesis of Heterocyclic Moieties Condensed with Pyrazole System under Green Conditions and Their Biological Activity. Green and Sustainable Chemistry, 6, 88-100. http://dx.doi.org/10.4236/gsc.2016.62008 
extended [4]. Pyrazoles exist in many compounds that are used as pharmaceuticals and agrochemicals [5]. Fused pyrazoles have fungicidal [6], herbicidal [7], veridical [8] and insecticidal activity [9] [10] and have been used for the treatment of rheumatoid arthritis [11] [12]. Beside the pharmaceutical importance pyrazoles are very important class of heterocycles due to their commercial uses in dyestuffs and food coloring agents [13].

In continuation to our program aiming at the synthesis of fused heterocyclic moities of anticipated biological activity, we report herein the eco-friendly synthesis of fused pyrazole derivatives [14]-[16].

\section{Materials and Methods}

\subsection{Chemistry}

Melting points were recorded on a Gallenkamp melting point apparatus and uncorrected. The infrared spectra were recorded on Perkin-Elmer FTIR 1430 spectrophotometer using the $\mathrm{KBr}$ disk technique. The ${ }^{1} \mathrm{H}$ NMR and ${ }^{13} \mathrm{C}$ NMR spectra were recorded on a Bruker AC spectrometer $(300 \mathrm{MHz})$ at $25^{\circ} \mathrm{C}$ in DMSO- $\mathrm{d}_{6}$ with TMS as internal standard and chemical shifts are reported in ppm as $\delta$ values. Reactions were conducted under microwave irradiation in closed vessels under magnetic stirring in a Synthos 3000 (Anton Paar) microwave with dual magnetrons system and with maximum power of $1000 \mathrm{~W}$. Mass spectra were measured on a Finnigan MAT 8222 EX mass spectrometer at $70 \mathrm{eV}$. Microanalyses were performed on Perkin-Elemer 2400 Elemental Analyzer at microanalytical center at Cairo University. Reaction progress was monitored by thin layer chromatography (TLC) using benzene/acetone ( $2 / 1$ by volume) as eluent. The strains for the biological activity were obtained from the Culture Collection of Bacteriology Laboratory, Microbiology Unit, Faculty of Science, Tanta University.

\subsubsection{Preparation of 4-Bromo-1-phenyl-3-(pyridin-3-yl)-1H-pyrazol-5(4H)-one 2}

1) Method A:

To a solution of 1-phenyl-3-pyridyl-5-pyrazolone 1 (4.74 g, 20 mmole) in chloroform (20 ml) add bromine (3.16 g, 20 mmole) dropwise at room temperature with stirring for $4 \mathrm{~h}$. The formed precipitate was filtrated; washed with chloroform, dried and crystallized from ethanol to give compound 2, m.p. $115^{\circ} \mathrm{C}-117^{\circ} \mathrm{C}(68 \%$ yield).

2) Method B:

To a solution of 1-phenyl-3-pyridyl-5-pyrazolone 1 (4.74 g, 20 mmole) and acetonitrile (20 ml) add a solution of NBSc (N-bromo sacharrine) (5.2 g, 20 mmole) in acetonitrile $(10 \mathrm{ml})$ dropwise at room temperature with stirring for $4 \mathrm{~h}$. The formed precipitate was filtrated; washed with chloroform, dried and crystallized from ethanol to give compound 2, (87\% yield) with same melting and mixed m.p.

IR $(\mathrm{KBr}) v / \mathrm{cm}^{-1}=2980\left(\mathrm{CH}_{\text {aliph }}\right), 1658(\mathrm{C}=\mathrm{O}), 1558(\mathrm{C}=\mathrm{N}), 748(\mathrm{C}-\mathrm{Br}) ;{ }^{1} \mathrm{H}$ NMR (DMSO): $\delta \mathrm{ppm}=7-7.64$ (m, 5H, ph-H), 7.66 - 8.83 (m, 4H, H-pyridine); ${ }^{13} \mathrm{C}$ NMR (DMSO): $\delta \mathrm{ppm}=49$ (C 4 pyridine), $120-132$ (Ar-C), 124 - 152 (py-C), 155 ( $\mathrm{C}_{4}$ pyridine), $160\left(\mathrm{C}=\mathrm{O}\right.$ ); Anal. Cald. For $\mathrm{C}_{14} \mathrm{H}_{10} \mathrm{BrN}_{3} \mathrm{O}$ (315.15); C, 53.17; H, 3.19; $\mathrm{Br}$, 25.27; N, 13.29: Found: C, 53.74; H, 3.34; $\mathrm{Br}, 25.65 ; \mathrm{N}, 13.88$; $\mathrm{MS}$ m/z $315\left(\mathrm{M}^{+}\right), 317\left(\mathrm{M}^{+2}\right)$.

\subsubsection{General Procedure for Synthesis of 4-Substituted}

5-Amino-1-phenyl-3-(pyridin-3-yl)-1H-furo[2,3-c]pyrazole (3-5)

A mixture of compound 2 (0.7 g, $2.2 \mathrm{mmol})$, malononitrile, cyanoacetamide and/or ethyl cyanoacetate (2.2 $\mathrm{mmol})$, chitosan $(0.5 \mathrm{~g})$ in dioxane $(20 \mathrm{ml})$ was refluxed for $8 \mathrm{~h}$. The reaction mixture was cooled, filtered and the filtrate was evaporated under reduced pressure, washed with diethyl ether and crystallized from ethanol to give compounds 3-5.

1) 5-Amino-4-cyano-1-phenyl-3-(pyridin-3-yl)- $1 H$-furo[2,3-c]pyrazole 3

m.p. $137^{\circ} \mathrm{C}-139^{\circ} \mathrm{C}$, yield $63 \%$; IR $(\mathrm{KBr}) \mathrm{v} / \mathrm{cm}^{-1}=3345\left(\mathrm{NH}_{2}\right), 2219(\mathrm{CN}), 1610(\mathrm{C}=\mathrm{N}) ;{ }^{1} \mathrm{H}$ NMR (DMSO): $\delta$ ppm = 4.47 (s, 2H, NH N $_{2}, 7.1-7.54$ (m, 5H, HPh), $7.44-8.13$ (dd, 4H, Hpyid); $\mathrm{C}^{13}$. NMR (DMSO): $\delta$ ppm $=$ 113 (CN), 99, 103 (2C, Fur), 122 - 135 (6C, Ph), 136 - 149 (5C, pyrid); Anal. Cald. For $\mathrm{C}_{17} \mathrm{H}_{11} \mathrm{~N}_{5} \mathrm{O}$ (310.15); C, 67.77; H, 3.68; N, 23.24: Found: C, 68, 13; H, 4.12; N, 23.64; MS m/z $310\left(\mathrm{M}^{+}\right)$.

2) Ethyl 2-(5-amino-1-phenyl-3-(pyridin-3-yl)-1H-furo[2,3-c]pyrazol-4-yl)acetate 4

m.p. $165^{\circ} \mathrm{C}-167^{\circ} \mathrm{C}$, yield $58 \%$; IR $(\mathrm{KBr}) \mathrm{v} / \mathrm{cm}^{-1}=3415\left(\mathrm{NH}_{2}\right), 2877\left(\mathrm{CH}_{\text {aliph }}\right), 1710(\mathrm{C}=\mathrm{O}), 1597(\mathrm{C}=\mathrm{N}) ;{ }^{1} \mathrm{H}$ NMR (DMSO): $\delta \mathrm{ppm}=1.23\left(\mathrm{t}, 3 \mathrm{H}, \mathrm{CH}_{3}\right), 4.23\left(\mathrm{q}, 2 \mathrm{H}, \mathrm{CH}_{2}\right), 4.65\left(\mathrm{~s}, 2 \mathrm{H}, \mathrm{NH}_{2}\right), 6.11-7.34(\mathrm{~m}, 5 \mathrm{H}, \mathrm{HPh}), 7.35-$ 8.84 (m, 4H, Hpyid); ${ }^{13} \mathrm{C}$. NMR (DMSO): $\delta$ ppm = $24\left(\mathrm{CH}_{3}\right), 66\left(\mathrm{CH}_{2}\right), 104,123$ (2C, Fur), 119 - 137 (6C, Ph), 
138 - 152 (5C, pyrid), 168 (C=O); Anal. Cald. For $\mathrm{C}_{18} \mathrm{H}_{15} \mathrm{~N}_{5} \mathrm{O}_{2}$ (362.15); C, 66.26; H, 5.04; N, 15.46: Found: C, 66.63; H, 5.26; N, 15.94; MS m/z $362\left(\mathrm{M}^{+}\right)$.

3) 2-(5-Amino-1-phenyl-3-(pyridin-3-yl)-1H-furo[2,3-c]pyrazol-4-yl)acetamide 5

m.p. $217^{\circ} \mathrm{C}-219^{\circ} \mathrm{C}$, yield $68 \%$; IR $(\mathrm{KBr}) \mathrm{v} / \mathrm{cm}^{-1}=3324\left(\mathrm{NH}_{2}\right), 2232\left(\mathrm{CONH}_{2}\right), 1680(\mathrm{C}=\mathrm{O}), 1610(\mathrm{C}=\mathrm{N}) ;{ }^{1} \mathrm{H}$ NMR (DMSO): $\delta \mathrm{ppm}=4.60$ (s, 2H, NH $\left.\mathrm{N}_{2}\right), 5.27\left(\mathrm{~s}, 2 \mathrm{H}, \mathrm{CONH}_{2}\right), 6.97-7.44$ (m, 5H, HPh), 7.33 - 8.54 (dd, 4H, Hpyid); ${ }^{13} \mathrm{C}$. NMR (DMSO): $\delta$ ppm = $173\left(\mathrm{CONH}_{2}\right), 104,123$ (2C, Fur), 119 - 137 (6C, Ph), 138 - 152 (5C, pyrid); Anal. Cald. For $\mathrm{C}_{18} \mathrm{H}_{15} \mathrm{~N}_{5} \mathrm{O}_{2}$ (333.05); C, 64.86; H, 4.54; N, 21.60: Found: C, 65.33; H, 4.96; N, 21.94; MS $\mathrm{m} / \mathrm{z} 333\left(\mathrm{M}^{+}\right)$.

\subsubsection{Cyclization of Compound 2 with p-Methoxy-Benzylidene Malononitrile}

Synthesis of 6-amino-4-(4-methoxyphenyl)-1-phenyl-3-(pyridin-3-yl)-1,4-dihydropyrano[2,3-c]pyrazole-5-carbonitrile 6 .

A mixture of compound 2 ( $1 \mathrm{~g}, 3.17$ mmole), p-methoxy-benzylidene malononitrile ( $0.56 \mathrm{~g}, 3.17 \mathrm{mmole})$, chitosan $(0.5 \mathrm{~g})$ in dioxane $(20 \mathrm{ml})$ was refluxed for $8 \mathrm{~h}$. The reaction mixture was cooled, filtered and the filtrate was evaporated under reduced pressure, washed with diethyl ether and crystallized from ethanol to give compound 6 .

m.p. $162^{\circ} \mathrm{C}-164^{\circ} \mathrm{C}$, yield 87\%; IR (KBr) v/cm ${ }^{-1}=3414\left(\mathrm{NH}_{2}\right), 2954\left(\mathrm{CH}_{3}\right.$ aliph $), 2362(\mathrm{CN}), 1587(\mathrm{C}=\mathrm{N}) ;{ }^{1} \mathrm{H}$ NMR (DMSO): $\delta$ ppm = 3.75 (s, 3H, $\mathrm{OCH}_{3}$ ), 4.61 (s, 2H, $\mathrm{NH}_{2}$ ), 4.82 (s, H, Hpyran), $6.68-7.56$ (m, 5H, Ph), 7.48 - 8.73 (m, 4H, pyid); Anal. Cald. For $\mathrm{C}_{25} \mathrm{H}_{19} \mathrm{~N}_{5} \mathrm{O}_{2}$ (421.45); C, 71.25; H, 4.54; N, 16.62; Found: C, 71.74; H, 4.91; N, 16.94; MS m/z $421\left(\mathrm{M}^{+}\right)$.

\subsubsection{General Procedure for Synthesis of Imidazo[4,5-c]pyrazole $(7,8)$}

A solution of compound 2 ( $0.7 \mathrm{~g}, 2.2 \mathrm{mmol})$, urea and/or guanidine $\mathrm{HCl}$ ( $2.2 \mathrm{mmole})$, chitosan $(0.5 \mathrm{~g})$ in dioxane $(20 \mathrm{ml})$ was refluxed for $4 \mathrm{~h}$. The reaction mixture was cooled, filtered and the filtrate was evaporated under reduced pressure, washed with diethyl ether and crystallized from ethyl acetate/ethanol to give compounds 7 , 8.

1) 1-Phenyl-3-(pyridin-3-yl)-1,4-dihydroimidazo[4,5-c]pyrazol-5-ol (7)

m.p. $214^{\circ} \mathrm{C}-216^{\circ} \mathrm{C}$, yield 63\%; IR $(\mathrm{KBr})$ v/cm ${ }^{-1}=3354(\mathrm{NH}, \mathrm{OH}), 3100\left(\mathrm{CH}_{\text {arom }}\right) 1597(\mathrm{C}=\mathrm{N}) ;{ }^{1} \mathrm{H}$ NMR (DMSO): $\delta$ ppm = 5.23 (s, H, OH), 11.23 (s, H, NH), $6.23-7.34$ (m, 5H, HPh), $7.35-8.84$ (m, 4H, Hpyid); ${ }^{13} \mathrm{C}$ NMR (DMSO): $\delta \mathrm{ppm}=122$ - 137 (6C, Ph), 138 - 152 (5C,pyrid), 168 (C,imid); Anal. Cald. For $\mathrm{C}_{15} \mathrm{H}_{12} \mathrm{~N}_{5} \mathrm{O}$ (277.15); C, 64.96; H, 4.04; N, 25.46: Found: C, 65.23; H, 4.326; N, 25.84; MS m/z 277(M $\left.{ }^{+}\right)$.

2) 1-Phenyl-3-(pyridin-3-yl)-1,4-dihydroimidazo[4,5-c]pyrazol-5-amine (8)

m.p. $234^{\circ} \mathrm{C}-236^{\circ} \mathrm{C}$, yield $63 \%$; IR $(\mathrm{KBr}) v_{\max } / \mathrm{cm}^{-1}=3329\left(\mathrm{NH}_{2}\right), 3055\left(\mathrm{CH}_{\text {arom }}\right) 1587(\mathrm{C}=\mathrm{N}) ;{ }^{1} \mathrm{H}$ NMR (DMSO): $\delta$ ppm = 5.11 (s, 2H, NH), $10.23\left(\mathrm{~s}, \mathrm{H}, \mathrm{NH}_{2}\right), 6.23$ - 7.34 (m, 5H, HPh), 7.35 - 8.84 (m, 4H, Hpyid); ${ }^{13} \mathrm{C}$ NMR (DMSO): $\delta \mathrm{ppm}=122-137$ (6C, Ph), $138-152$ (5C, (277.15); C, 65.22; H, 4.38; N, 30.42: Found: C, 65.63; H, 4.66; N, 30.84; MS m/z 276 ( $\left.\mathrm{M}^{+}\right)$.

\subsubsection{Synthesis of 1-Phenyl-3-(pyridin-3-yl)-1H-pyrazolo[3,4- $d]$ thiazol-5-amine (9)}

A solution of compound 2 ( $0.7 \mathrm{~g}, 2.2 \mathrm{mmol}),(0.17 \mathrm{~g}, 2.2$ mmole) thiourea, chitosan ( $0.5 \mathrm{~g})$ in dioxane (20 ml) was refluxed for $4 \mathrm{~h}$. The reaction mixture was cooled, filtered and the filtrate was evaporated under reduced pressure, washed with diethyl ether and crystallized from ethylacetate/ethanol to give compound 9; m.p. $242^{\circ} \mathrm{C}$ $244^{\circ} \mathrm{C}$, yield 68\%; IR (KBr) v/cm ${ }^{-1}=3340\left(\mathrm{NH}_{2}\right), 3055\left(\mathrm{CH}_{\text {arom }}\right) 1587(\mathrm{C}=\mathrm{N}), 1180$ (C-S); ${ }^{1} \mathrm{H}$ NMR (DMSO): $\delta$ ppm = 10.23 (s, H, $\mathrm{NH}_{2}$ ), $6.23-7.34$ (m, 5H, HPh), 7.35 - 8.84 (m, 4H, Hpyid); Anal. Cald. For $\mathrm{C}_{15} \mathrm{H}_{11} \mathrm{~N}_{5} \mathrm{~S}$ (293.25); C, 61.42; H, 3.87; N, 23.77; S, 10.93: Found: C, 61.93; H, 4.21; N, 24.04; S, 11.14; MS m/z 293( $\left.{ }^{+}\right)$.

\subsubsection{Cyclization of Compound 8 with $\beta$-Ketoester}

1) Formation of substituted pyrazol[4,3-b]thiazolo[3,2-a]pyrimidine-7-one 10, 11

A mixture of compound 9 ( $1 \mathrm{~g}, 3.4$ mmole), ethylacetoacetate and/or ethylbenzoylacetate (3.4 mmole), chitosan $(0.5 \mathrm{~g})$ in dioxane $(20 \mathrm{ml})$ was refluxed for $6 \mathrm{~h}$. The reaction mixture was cooled, filtered and the filtrate was evaporated under reduced pressure, washed with diethyl ether and crystallized from ethanol to give compounds $10,11$.

2) 5-Methyl-pyrazol[4,3-b]thiazolo[3,2-a]pyrimidine-7-one 10

m.p. $185^{\circ} \mathrm{C}-187^{\circ} \mathrm{C}$, yield $87 \%$; IR $(\mathrm{KBr}) \mathrm{v} / \mathrm{cm}^{-1}=2890\left(\mathrm{CH}_{3 \mathrm{aliph}}\right), 1690(\mathrm{C}=\mathrm{O}), 1587(\mathrm{C}=\mathrm{N}), 1460(\mathrm{C}=\mathrm{C})$, 
1210 (C-S); ${ }^{1} \mathrm{H}$ NMR (DMSO): $\delta$ ppm = 2.11 (s, 3H, $\mathrm{CH}_{3}$ ), 6.23 (s, H, Hpyrimid.), 7.12 - 7.34 (m, 5H, HPh), 7.45 - 8.84 (m, 4H, Hpyrid.); Anal. Cald. For $\mathrm{C}_{19} \mathrm{H}_{13} \mathrm{~N}_{5} \mathrm{OS}$ (359.15); C, 63.42; H, 3.67; N, 19.47; S, 8.92: Found: C, 63.53; H, 3.91; N, 19.94; S, 9.32: MS m/z $359\left(\mathrm{M}^{+}\right)$.

3) 5-Phenyl-pyrazol[4,3-b]thiazolo[3,2-a]pyrimidine-7-one 11

$205^{\circ} \mathrm{C}-207^{\circ} \mathrm{C}$, yield 68\%; IR $\left.(\mathrm{KBr}) \mathrm{v} / \mathrm{cm}^{-1}=3055\left(\mathrm{CH}_{\text {arom }}\right), 1677(\mathrm{C}=\mathrm{O}), 1594(\mathrm{C}=\mathrm{N})\right), 1178(\mathrm{C}-\mathrm{S}) ;{ }^{1} \mathrm{H}$ NMR (DMSO): $\delta$ ppm = 6.08 (s, H, Hpyrimid.), 6.74 - 7.22 (m, 5H, HPh), 7.35 - 8.65 (m, 4H, Hpyid); Anal. Cald. For $\mathrm{C}_{24} \mathrm{H}_{15} \mathrm{~N}_{5} \mathrm{OS}$ (421.05); C, 68.32; H, 3.57; N, 16.62; S, 7.61: Found: C, 68.73; H, 4.11; N, 16.94; S, 7.96; MS m/z $421\left(\mathrm{M}^{+}\right)$.

\subsubsection{Cyclization of Compound 2 with $\beta$-Mercapto Derivatives (12-14)}

A mixture of compound 2 (0.6 g, $20 \mathrm{mmol})$, appropriate reagent cysteine, ethyl mercapto acetate and/or 2-mercapto ethanol (20 mmole), and chitosan $(0.5 \mathrm{~g})$ in dry dioxane $(10 \mathrm{ml})$, was refluxed for $4 \mathrm{~h}$. The reaction mixture was cooled, filtered and the filtrate evaporated under reduced pressure; the residue was triturated with pet.ether $40^{\circ} \mathrm{C}-60^{\circ} \mathrm{C}$. The obtained products were refluxed in glacial acetic acid $(10 \mathrm{ml})$ for $2 \mathrm{~h}$. The reaction mixture was cooled and poured into ice water to give compounds (12-14).

\subsubsection{1-Phenyl-3-(pyridin-3-yl)-1,5,6,7-tetrahydropyrazolo[4,3-b][1,4]thiazine-6-carboxylic Acid}

m.p. $182^{\circ} \mathrm{C}-194^{\circ} \mathrm{C}$, yield 90\%; IR (KBr) v/cm ${ }^{-1}=3342(\mathrm{OH}, \mathrm{NH}), 2885\left(\mathrm{CH}_{\text {2aliph }}\right), 1710(\mathrm{C}=\mathrm{O}), 675$ (C-S); ${ }^{1} \mathrm{H}$ NMR (DMSO): $\delta$ ppm = 3.5 (d, 2H, $\left.\mathrm{CH}_{2}-\mathrm{S}\right), 3.76$ (t, H, CH-N), 4.52 (s, H, NH), 6.67 - 7.41 (m, 5H, HPh), 7.43 8.92 (m, 4H, Hpyid), 11.23 (s, H, COOH); Anal. Cald. For $\mathrm{C}_{17} \mathrm{H}_{14} \mathrm{~N}_{4} \mathrm{O}_{2} \mathrm{~S}$ (338.08); C, 60.34; H, 4.17; N, 16.57; S, 9.48: Found: C, 60.83; H, 4.31; N, 16.94; S, 9.76; MS m/z $338\left(\mathrm{M}^{+}\right)$.

1) 1-Phenyl-3-(pyridin-3-yl)-5,6-dihydro-1H-[1,4] oxathiino[2,3-c]pyrazol-6-ol (13)

m.p. $211^{\circ} \mathrm{C}-213^{\circ} \mathrm{C}$, yield 85\%; IR (KBr) v/cm ${ }^{-1}=3421(\mathrm{OH}), 2891\left(\mathrm{CH}_{2 a l i p h}\right), 665(\mathrm{C}-\mathrm{S}), 1156(\mathrm{C}-\mathrm{O}) ;{ }^{1} \mathrm{H}$ NMR (DMSO): $\delta$ ppm = 3.44 (d, 2H, $\left.\mathrm{CH}_{2}-\mathrm{S}\right), 4.2$ (t, H, CH-O), 6.1 (s, H, OH), 7.21 - 7.54 (m, 5H, HPh), 7.55 8.67 (m, 4H, Hpyid); Anal. Cald. For $\mathrm{C}_{16} \mathrm{H}_{13} \mathrm{~N}_{3} \mathrm{O}_{2} \mathrm{~S}$ (311.36); C, 61.72; H, 4.21; N, 13.50; S, 10.30; Found: C, 62.03; H, 4.62; N, 13.87; S, 10.56: MS m/z $312\left(\mathrm{M}^{+}\right)$.

2) 1-Phenyl-3-(pyridin-3-yl)-5,6-dihydro-1H-[1,4]oxathiino[2,3-c]pyrazole (14)

m.p. $165^{\circ} \mathrm{C}-168^{\circ} \mathrm{C}$, yield $82 \%$; IR $(\mathrm{KBr}) \mathrm{v} / \mathrm{cm}^{-1}=2884\left(\mathrm{CH}_{2 \text { aliph }}\right), 1574(\mathrm{C}=\mathrm{N}), 670(\mathrm{C}-\mathrm{S}), 1172(\mathrm{C}-\mathrm{O}) ;{ }^{1} \mathrm{H}$ NMR (DMSO): $\delta$ ppm = 3.36 (t, 2H, $\left.\mathrm{CH}_{2}-\mathrm{S}\right), 4.15$ (t, 2H, $\left.\mathrm{CH}_{2}-\mathrm{O}\right), 7.32$ - 7.44 (m, 5H, HPh), 7.45 - 8.56 (m, 4H, Hpyid); Anal. Cald. For $\mathrm{C}_{16} \mathrm{H}_{13} \mathrm{~N}_{3} \mathrm{OS}$ (295.35); C, 65.06; H, 4.44; N, 14.23; S, 5.42; Found: C, 65.33; H, 4.72; N, 14.54; S, 11.16: MS m/z 295( $\left.\mathrm{M}^{+}\right)$.

\subsubsection{Condensation of 2 with $o$-Aminopheno and/or $o$-Phenylene Diamine}

1) Formation of pyrazolo[3,4-b]benzoxazine and pyrazolo[3,4-b]quinoxaline $(15,16)$

A mixture of compound 2 ( $0.6 \mathrm{~g}, 20 \mathrm{mmol})$, o-aminophenol and/or o-phenylene diamine (20 mmole) and chitosan $(0.5 \mathrm{~g})$ in dry dioxane $(20 \mathrm{ml})$ was heated under reflux for $6 \mathrm{~h}$. The reaction mixture was cooled and filtered. The filtrate evaporated under reduced pressure and the residue was triturated with pet.ether $40^{\circ} \mathrm{C}-60^{\circ} \mathrm{C}$. The obtained products were refluxed in $10 \mathrm{ml}$ glacial acetic acid for $2 \mathrm{~h}$. The reaction mixture was cooled and poured into ice water to give compounds $\mathbf{1 5}, \mathbf{1 6}$.

2) 1-Phenyl-3-(pyridin-3-yl)-4,9-dihydro-1H-pyrazolo[3,4-b]benzoxazine (15)

m.p. $226^{\circ} \mathrm{C}-228^{\circ} \mathrm{C}$, yield 80\%; IR (KBr) v/ $\mathrm{cm}^{-1}=3346$ (NH), 1170 (C-N), 1155 (C-O); ${ }^{1} \mathrm{H}$ NMR (DMSO): $\delta$ ppm = 4.56 (s, H, NH), 6.5 - $7.44(10 \mathrm{H}$,aromatic $), 7.53$ - $8.71\left(\mathrm{~m}, 4 \mathrm{H}_{\text {,pyid }}\right)$; Anal. Cald. For $\mathrm{C}_{20} \mathrm{H}_{14} \mathrm{~N}_{4} \mathrm{O}$ (326.13); C, 73.61; H, 4.34; N, 17.17; Found: C, 73.92; H, 4.75; N, 17.54; MS m/z $326\left(\mathrm{M}^{+}\right)$.

3) 1-Phenyl-3-(pyridin-3-yl)-4,9-dihydro-1 $H$-pyrazolo[3,4-b]quinoxaline (16)

m.p. $226^{\circ} \mathrm{C}-228^{\circ} \mathrm{C}$, yield 80\%; IR (KBr) v/cm ${ }^{-1}=3353(\mathrm{NH}), 1240$ (C-N), 1206 (C-O); ${ }^{1} \mathrm{H}$ NMR (DMSO): $\delta$ ppm = 4.44 (s, 2H, NH), 7.32 - 7.44 (m, 5H, Ph), 7.45 - 8.56 (m, 4H, pyid); Anal. Cald. For $\mathrm{C}_{20} \mathrm{H}_{15} \mathrm{~N}_{5}$ (325.34); C, 73.83; H, 4.65; N, 21.52; Found: C, 74.02; H, 4.83; N, 21.75: MS m/z $325\left(\mathrm{M}^{+}\right)$.

\subsection{Antimicrobial Assay}

An aliquot of $0.1 \mathrm{ml}$ of each bacterial strain was inoculated and spread on nutrient agar while $0.1 \mathrm{ml}$ of the yeast was spread on sabaroud agar slopes. Antimicrobial activity of the synthesized compounds was tested in vitro 
against different types of bacteria and one fungal strain by the cut plug method [17]. The assay plates were inoculated with $100 \mathrm{ml}$ containing the diluted inoculums $(107 \mathrm{CFU} / \mathrm{ml})$ of each tested organism that were spread on the corresponding media. After solidification, the wells were made and $10 \mathrm{mg}$ of the synthesized chemicals were dissolved in $1 \mathrm{ml}$ DMSO and inserted in the wells. Nutrient agar plated was incubated at $37^{\circ} \mathrm{C}$ for $24 \mathrm{~h}$ while plates were incubated at $25^{\circ} \mathrm{C}$ for $48 \mathrm{~h}$. The zones of inhibition around the wells were measured and the average based on three replies was recorded.

\subsection{DPPH Radical Scavenging Assay}

The antioxidant activities of the tested compounds were measured by using DPPH radical scavenging assay with L-ascorbic acid as drug reference [18]. Each tested sample and L-ascorbic acid (50 $\mu \mathrm{g})$ was dissolved in $1 \mathrm{ml}$ DMSO. The dissolved sample (250 ml) was added to $1 \mathrm{ml}$ DPPH/DMSO solution $(6 \mu \mathrm{g} / 50 \mathrm{ml})$ and the total volume was adjusted to $3 \mathrm{ml}$ with DMSO. An equal amount of DMSO was used as a control. After vortexing the mixture was incubated for $30 \mathrm{~min}$ in dark at room temperature. Absorbance was measured using a spectrophotometer at $517 \mathrm{~nm})$. DPPH radical scavenging $\%=1 /($ A sample $/$ A control $) \times 100$. Serial dilutions $(5-50 \mu \mathrm{g} / \mathrm{ml})$ of each compound were measured by the same assay to obtain the IC50 according to Brand-Williams et al. [19].

\section{Results and Discussion}

\subsection{Chemistry}

The synthetic routes for the synthesis of compounds 2-16 are outlined in (Schemes 1-5).

The key intermediate 4-bromo-1-phenyl-3-(pyridin-3-yl)-1H-pyrazol-5(4H)-one 2 is the building block for the synthesis of fused pyrazolo moieties provide synergistic cytotoxic activity. The presence of a pyridyl group in position 3 gave a slightly basic effect; beside the pyridine moiety is ubitiquitous in natural products having tremendous physiological properties [20]-[22].

The key intermediate $\mathbf{2}$ was easily prepared from 1-phenyl-3-pyridyl-5-pyrazolone $\mathbf{1}$ [23] by bromination with N-bromosaccharine (sodium salt of saccharine with potassium bromide and oxone in water at room temperature) in $90 \%$ yield (Scheme 1). It is worthy mentioning that the classical bromination methods (bromine and/or Nbromo-succinamide in chloroform) the yield did not exceed $68 \%$.

The I.R spectrum of compound 2 shows a strong absorption band at $v 1558 \mathrm{~cm}^{-1}(\mathrm{C}=\mathrm{O})$ and a band at $v 748$ $\mathrm{cm}^{-1}(\mathrm{C}-\mathrm{Br})$. The ${ }^{1} \mathrm{H}$ NMR and mass spectrum of the prepared compound confirm the structure.

The base catalyzed reaction of compound 2 with some active methylene reagents as malononitrile, ethyl cynoacetate and ethyl cyanoacetamide was carried out by using the heterogeneous basic catalyst chitosan in dioxane or diphenyl ether to give the corresponding furopyrazole moieties 5-amino-4-cyano-1-phenyl-3-(pyridin3-yl)- $1 H$-furo[2,3-c]pyrazole 3, ethyl-5-amino-1-phenyl-3-(pyridin-3-yl)- $1 H$-furo[2,3-c]pyrazole-4-car-boylate 4 and 5-amino-1-phenyl-3-(pyridin-3-yl)-1H-furo[2,3-c]pyrazole-4-carboxamide 5 respectively (Scheme 1 ).

The structure of compounds 3-5 was proved on the basis of analytical and spectral data. Thus IR spectrum for compound 3 shows bands at $v 3345 \mathrm{~cm}^{-1}\left(\mathrm{NH}_{2}\right), v 2219 \mathrm{~cm}^{-1}(\mathrm{CN})$ and the disappearance of $v \mathrm{C}=\mathrm{O}$ band. The ${ }^{1} \mathrm{H}$ NMR spectrum for compound 3 showed the presence of a singlet for $\mathrm{NH}_{2}$ protons at $\delta 4.47 \mathrm{ppm}$ which disappeared by mixing with $\mathrm{D}_{2} \mathrm{O}$. The IR spectrum for compound $\mathbf{4}$ shows bands at $v 3324 \mathrm{~cm}^{-1}\left(\mathrm{NH}_{2}\right), v 3350$ $\mathrm{cm}^{-1}\left(\mathrm{NH}_{2 \text { amide }}\right)$ and $v 1680 \mathrm{~cm}^{-1}(\mathrm{C}=\mathrm{O})$. The ${ }^{1} \mathrm{H}$ NMR spectrum of compound 4 shows the presence of a singlet for $\mathrm{NH}_{2}$ protons at $\delta 5.27 \mathrm{ppm}$. All spectroscopic and analytical data are given in experimental part.

The IR spectrum for compound 5 shows bands at $v 3415 \mathrm{~cm}^{-1}\left(\mathrm{NH}_{2}\right), v 1710 \mathrm{~cm}^{-1}$ (C=O ester). The ${ }^{1} \mathrm{H}$ NMR spectrum of compound 5 showed triplet for $\mathrm{CH}_{3}$ at $\delta 1.23 \mathrm{ppm}$, quartet for $\mathrm{CH}_{2}$ at $\delta 4.23 \mathrm{ppm}$ for ester protons and a singlet for $\mathrm{NH}_{2}$ protons at $\delta 4.65 \mathrm{ppm}$. All spectroscopic and analytical data are given in experimental part.

The reaction of compound 2 with 2-(4-methoxybenzylidene) malononitrile in dioxane in the presence of chitosan as a green catalyst gave the corresponding 6-imino-4-(4-methoxyphenyl)-1-phenyl-3-(pyridin-3-yl)-1,4, 5,6-tetrahydro- pyrano[2,3-c]pyrazole-5-carbonitrile 6 (Scheme 2).

The structure of compound 6 was proved by spectral data, IR spectrum showed bands at $v 3414 \mathrm{~cm}^{-1}\left(\mathrm{NH}_{2}\right), v$ $2954 \mathrm{~cm}^{-1}\left(\mathrm{CH}_{3 a \mathrm{aliph}}\right)$ and $v 2362 \mathrm{~cm}^{-1}(\mathrm{CN})$. The ${ }^{1} \mathrm{H}$ NMR spectrum of compound 6 showed a singlet for $\mathrm{OCH}_{3}$ at $\delta 3.75 \mathrm{ppm}$, a singlet for $\mathrm{NH}_{2}$ protons at $\delta 4.61 \mathrm{ppm}$ and a singlet proton of pyrane ring at $\delta 4.82 \mathrm{ppm}$. All spectroscopic and analytical data are given in experimental part. 


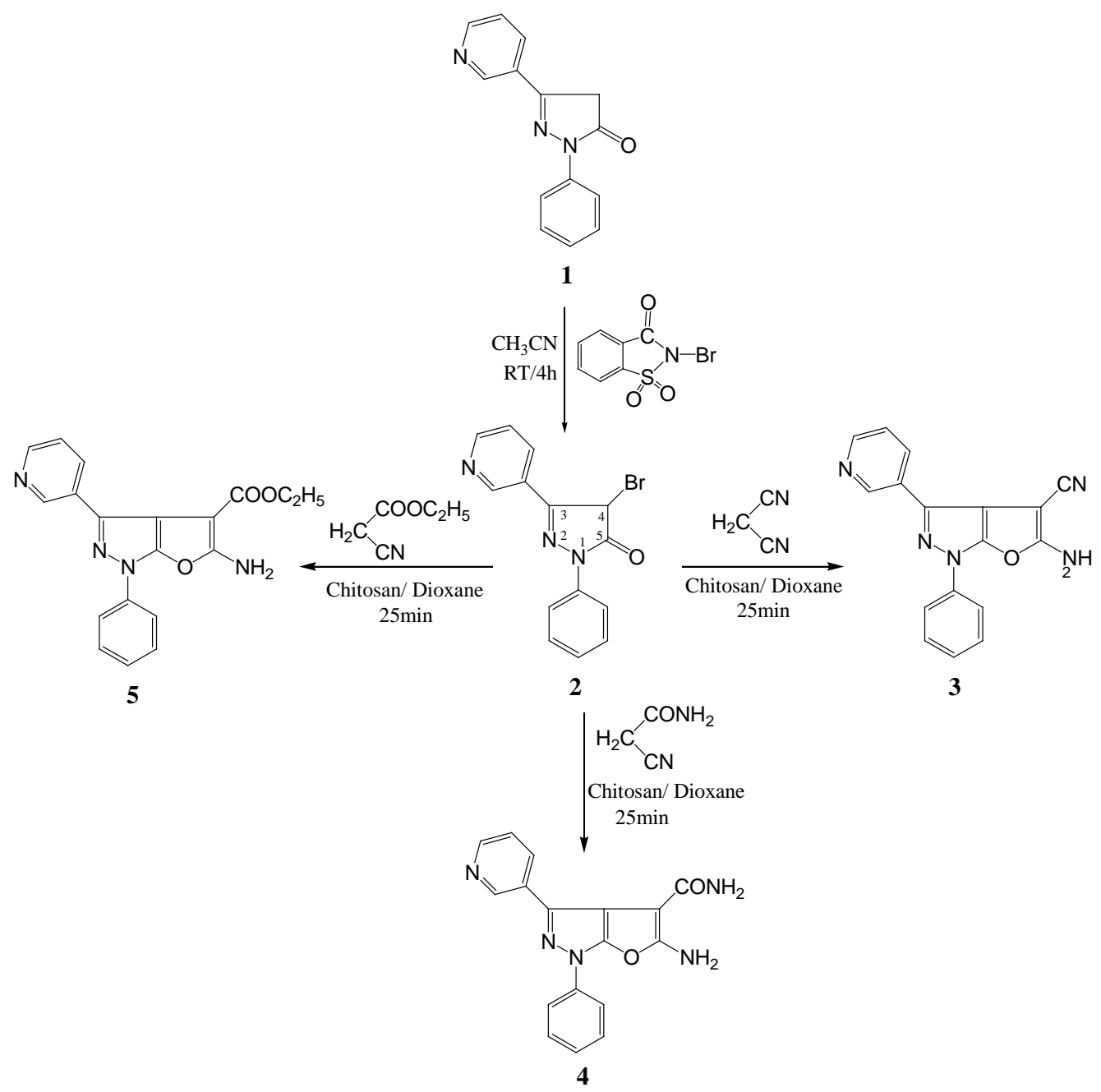

Scheme 1 Preparation of 4-substituted 5-amino-1-phenyl-3-(pyridin-3-yl)-1H-furo[2,3-c]pyrazole 2-5

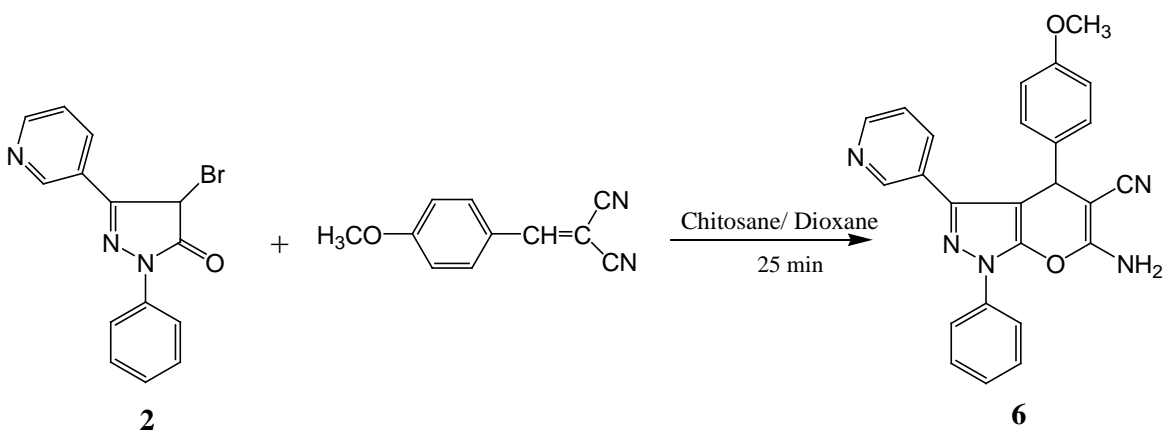

Scheme 2 Preparation of 6-imino-4-(4-methoxyphenyl)-1-phenyl-3-(pyridin-3-yl)-1,4,5,6-tetrahydro- pyrano[2,3-c]pyrazole-5-carbonitrile 6

The reaction of compound $\mathbf{2}$ with urea, guanidine hydrochloride and thiourea in dioxane in the presence of chitosan gave the corresponding imidazopyrazoles $\mathbf{7}$ and $\mathbf{8}$ or pyrazolothiazole $\mathbf{9}$ respectively (Scheme 3).

The structure of compounds 7-9 was confirmed by analytical and spectral data. The IR spectram showed bands at $v 3329-3354 \mathrm{~cm}^{-1}\left(\mathrm{OH}, \mathrm{NH}_{2}\right)$ and disappearance of $v \mathrm{C}-\mathrm{Br}$ and $v \mathrm{C}=\mathrm{O}$ bands. ${ }^{1} \mathrm{H}$ NMR spectram for compounds 7 and 8 showed a singlet $\mathrm{NH}$ proton of imidazole moiety at $\delta 11.23 \mathrm{ppm}$. All spectroscopic and analytical data are given in experimental part. 


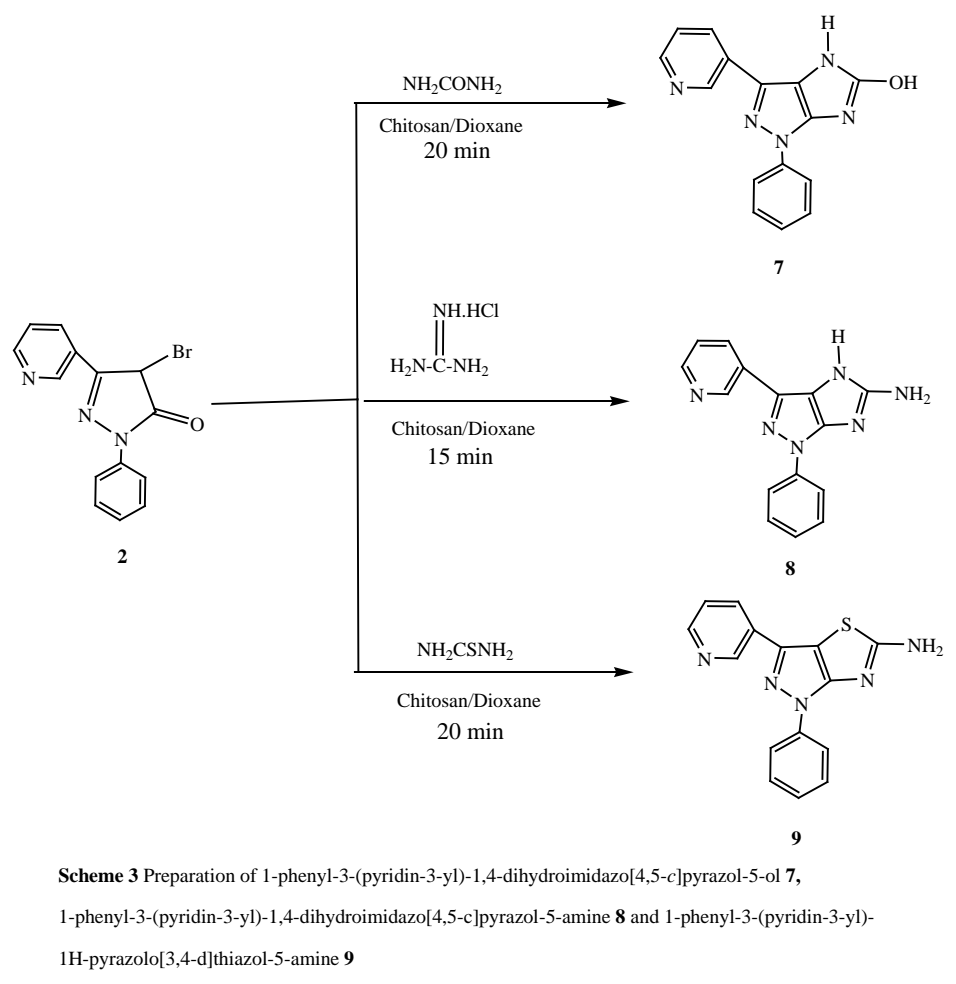

On the other hand, the reaction of compound 9 with some ketoesters named ethyl acetoacetate and ethyl benzoylacetate in dioxane in the presence of chitosan gave the corresponding 5-substituted pyrazol[4,3-b] thiazolo[3,2- $a]$ pyrimidine-7-ones $\mathbf{1 0}$ and $\mathbf{1 1}$ respectively (Scheme 4).

The structure of compounds $\mathbf{1 0}$ and $\mathbf{1 1}$ was proved on the basis of analytical and spectral data. The IR spectrum showed bands at $v 1677-1690 \mathrm{~cm}^{-1}(\mathrm{C}=\mathrm{O})$, and disappearance of $v\left(\mathrm{NH}_{2}\right)$ group. ${ }^{1} \mathrm{H}$ NMR spectrum showed a singlet pyrimidine ring proton at $\delta 6.08-6.23 \mathrm{ppm}$ and a singlet for $\mathrm{CH}_{3}$ protons at $\delta 2.11 \mathrm{ppm}$ for compound 10. All spectroscopic and analytical data are given in experimental part.

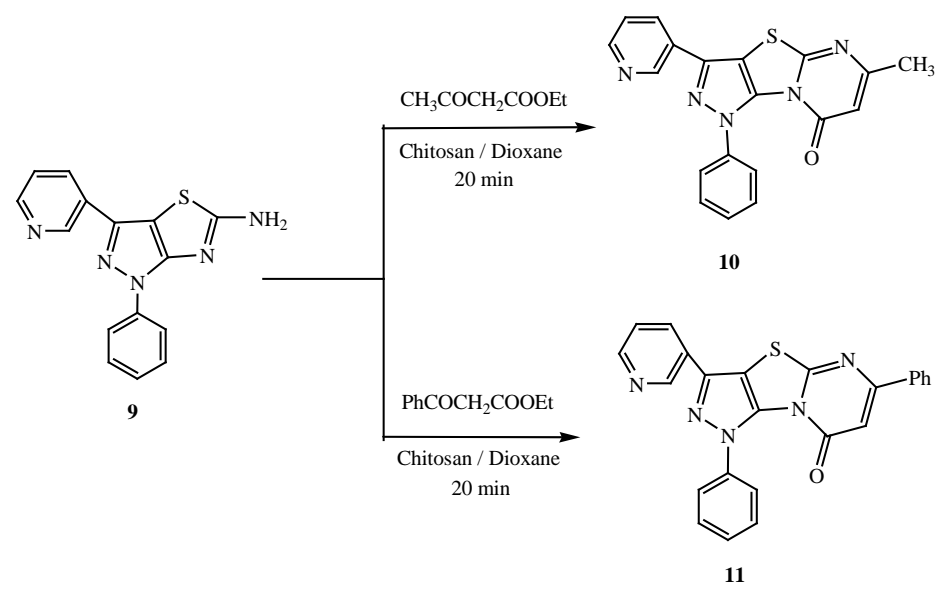

Scheme 4 Preparation of 5-substituted pyrazol[4,3-b]thiazolo[3,2-a]pyrimidine-7-one $\mathbf{1 0}$ and $\mathbf{1 1}$

Also, the reaction of compound $\mathbf{2}$ with some mercapto derivatives as cysteine, ethyl mercaptoacetate and mercaptoethanol in dioxane in the presence of chitosan as a green catalyst gave the corresponding fused pyrazolo derivatives 1-phenyl-3-(pyridin-3-yl)-1,5,6,7-tetrahydropyrazolo[4,3-b][1,4]thiazine-6-carboxylic acid 12, 1phenyl-3-(pyridin-3-yl)-5,6-dihydro-1 $H$-[1,4]oxathiino[2,3-c]pyrazol-6-ol 13 and 1-phenyl-3-(pyridin-3-yl)-5,6dihydro- $1 H$-[1,4]oxathiino[2,3-c]pyrazole 14 respectively (Scheme 5). 
The structure of compounds 12-14 was proved on the basis analytical and spectral data. The IR spectrum of compound 12 showed bands at $v 3342 \mathrm{~cm}^{-1}(\mathrm{OH}), v 1710 \mathrm{~cm}^{-1}(\mathrm{C}=\mathrm{O})$ of carboxylic group and $v 675 \mathrm{~cm}^{-1}$ (CS). Also, ${ }^{1} \mathrm{H}$ NMR spectrum showed doublet and triplet for $\mathrm{CH}_{2}$ and $\mathrm{CH}$ of thiazine ring protons at $\delta 3.44$ and $4.20 \mathrm{ppm}$ respectively and a singlet of carboxylic proton at $\delta 11.23 \mathrm{ppm}$. The IR spectram of compounds $\mathbf{1 3}$ and 14 showed bands at $v 2891,2884 \mathrm{~cm}^{-1}\left(\mathrm{CH}_{2}\right.$ aliph. of oxazine ring) respectively. Also, ${ }^{1} \mathrm{H}$ NMR spectrum of compound 13 showed doublet and triplet $\mathrm{CH}_{2}$ and $\mathrm{CH}$ of oxazine ring protons at $\delta 3.44$ and 4.20 ppm respectively, while, The ${ }^{1} \mathrm{H}$ NMR spectrum of compound $\mathbf{1 4}$ showed two triplet signals for two $\mathrm{CH}_{2}$ protons of oxazine ring at $\delta 3.36$ and $4.15 \mathrm{ppm}$ respectively. All spectroscopic and analytical data are given in experimental part.

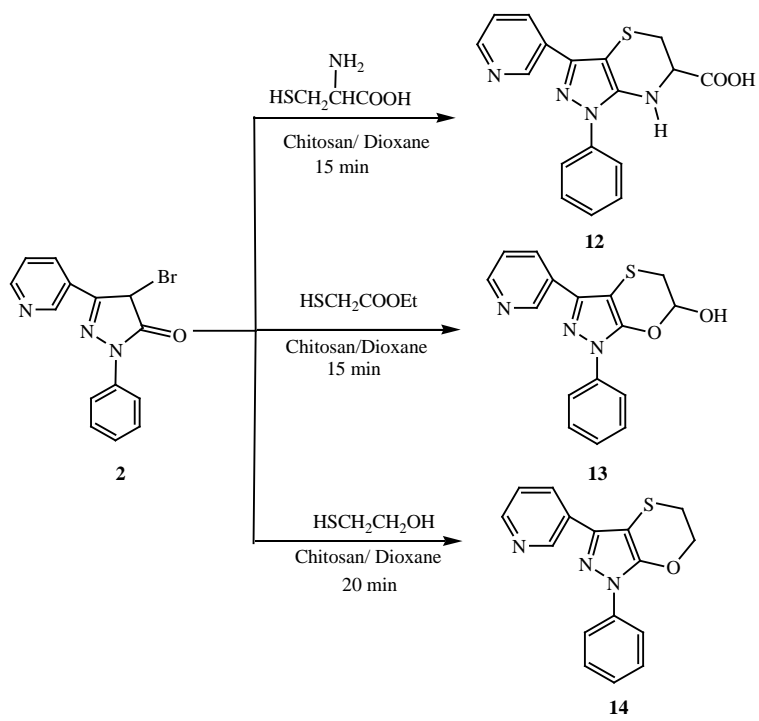

\footnotetext{
Scheme 5 Preparation of1-phenyl-3-(pyridin-3-yl)-1,5,6,7-tetrahydropyrazolo[4,3-b][1,4]thiazine-6-carboxylic acid 12,

1-phenyl-3-(pyridin-3-yl)-5,6-dihydro-1H-[1,4]oxathiino[2,3-c]pyrazol-6-ol 13 and 1-phenyl-3-(pyridin-3-yl)-5,6-

dihydro-1H-[1,4] oxathiino[2,3-c]pyrazole 14
}

Finally, the reaction of compound $\mathbf{2}$ with $o$-amino phenol and $o$-phenylenediamine in the presence of dioxane gave the pyrazolo[3,4-b]benzo(e)[1,4] oxazine $\mathbf{1 5}$ and pyrazolo[3,4-b]quinoxaline $\mathbf{1 6}$ respectively (Scheme 6).

The structure of compounds $\mathbf{1 5}$ and $\mathbf{1 6}$ was proved by analytical and spectral data. The IR spectrum showed bands at $v 3346,3352 \mathrm{~cm}^{-1}(\mathrm{NH})$ and disappearance of $v \mathrm{C}=\mathrm{O}$ and $v \mathrm{C}-\mathrm{Br}$ bands. The ${ }^{1} \mathrm{H}$ NMR spectrum showed multiplet at $\delta 6.50-8.71$ and 7.32 - 8.56 ppm respectively corresponding to aromatic and heteroaromatic protons. All spectroscopic and analytical data are given in experimental part.

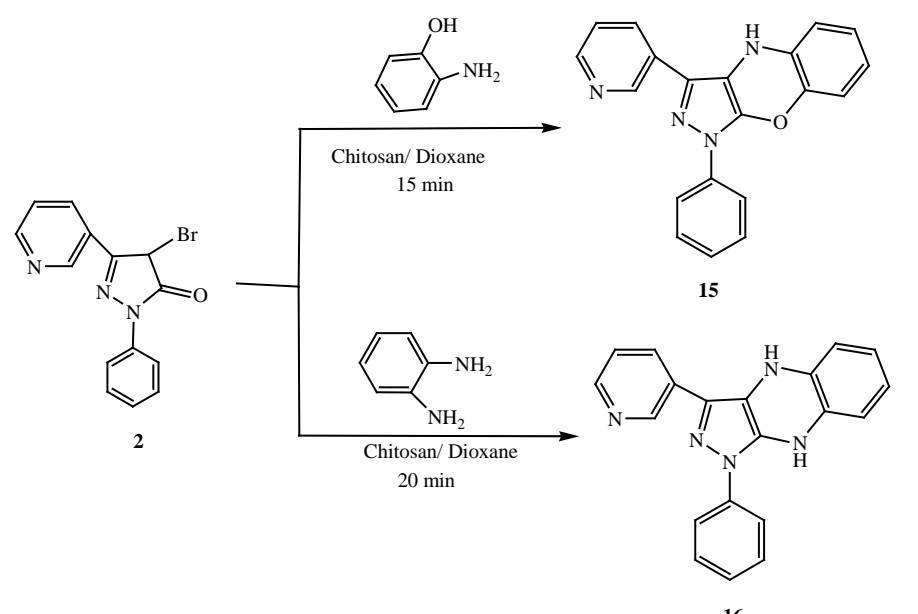

Scheme 6 Preparation of pyrazolo[3,4-b]benzo(e)[1,4]oxazine 15 and pyrazolo[3,4-b]quinoxaline 16 
The microwave irradiation technique as a source of energy was used. Under this technique interesting results were obtained in which the reaction time was reduced from 4-8 hours to only few minutes (15 - $25 \mathrm{~min}$.) and the yields were increased from $50 \%-82 \%$ to $80 \%-92 \%$. Also, the products obtained are more pure than that obtained by conventional heating procedure (Table 1 ).

\subsection{Pharmacology}

\subsubsection{Antimicrobial Evaluation}

Throughout history, there has been a continual battle between humans and the multitude of microorganisms that cause infection and disease. Diseases caused by microbial infection are a serious menace to the health of human beings and often have connection to some other diseases whenever the body system gets debilitated. During the $20^{\text {th }}$ century, vaccines for bacterial toxins and many other common acute viral infections were developed and made widely available.

The antimicrobial properties of the synthesized compounds 7-16 were tested against Gram-negative bacteria (Klibsella, E. coli, Serratia and Citrobacter), Gram-positive bacteria (Bacillus subtilis, Bacillus cereus, Pseudomonas vulgarus and Staphylococcus aureus) along with the non-filamentous fungus (Candida albicans) along with the non-filamentous fungus (Candida albicans) as pathogenic bacterial strains. Three different broadly used antibiotics (Amoxycilline, Chlormphenicol and Tetracycline) were used as references.

Reviewing the antimicrobial activity data (Table 2), it is concluded that compound $\mathbf{9}$ and compound $\mathbf{1 6}$ is the most active among all the synthesized compounds against most of the tested organisms, while compounds 7, 8 and 12-15 were found to have slight or moderate activity. It is worthy mentioning that minor change in molecular configuration of these compounds profoundly influences the biological activities.

Minimum inhibitory concentration (MIC) is important in diagnostic laboratories to confirm resistance microorganisms to an antimicrobial agent and also to monitor the activity of new antimicrobial agents. An MIC is generally regarded as the most basic measurement of the activity of an antimicrobial agent against organism. The present data shows that the most sensitive organism to the tested compound $\mathbf{9}$ is Candida albicans, Staphylo coccusaures, Citrobacter, Bacillus cereus and E. coli which showed (MIC) value of 250, 180, 250, 250 and 250 respectively. While, the most sensitive organism to the tested compound $\mathbf{1 6}$ is Candida albicans, Bacillus subtilis and Pseudonas vulgarus which showed (MIC) value of 250, 180 and 250 respectively compared with other (MIC) for the other organisms (Table 3).

Table 1. Experimental data for the synthesis of compounds 2-8 by traditional methods and microwave assisted methods.

\begin{tabular}{|c|c|c|c|c|c|c|}
\hline \multirow{3}{*}{$\begin{array}{c}\begin{array}{c}\text { Comp. } \\
\text { no }\end{array} \\
3 \\
\end{array}$} & \multicolumn{2}{|c|}{ Time } & \multicolumn{4}{|c|}{ Yield (\%) } \\
\hline & \multirow{2}{*}{$\begin{array}{c}\begin{array}{c}\text { Micro. Irr. } \\
\left(120^{\circ} \mathbf{C}-\mathbf{1 3 0}^{\circ} \mathbf{C}\right)\end{array} \\
25 \mathrm{~min}\end{array}$} & \multirow{2}{*}{$\begin{array}{c}\begin{array}{c}\text { Conv. H. } \\
\text { (reflux) }\end{array} \\
8 \mathrm{~h}\end{array}$} & \multicolumn{2}{|c|}{$\begin{array}{l}\text { Microwave } \\
\text { irradiation }\end{array}$} & \multicolumn{2}{|c|}{$\begin{array}{c}\text { Conventional } \\
\text { heating }\end{array}$} \\
\hline & & & $90^{\mathrm{a}}$ & $87^{c}$ & $67^{\mathrm{a}}$ & $60^{\circ}$ \\
\hline 4 & $25 \mathrm{~min}$ & $8 \mathrm{~h}$ & $89-92^{\mathrm{a}}$ & $87^{c}$ & $65^{\mathrm{a}}$ & $63^{\circ}$ \\
\hline 5 & $25 \mathrm{~min}$ & $8 \mathrm{~h}$ & $92^{\mathrm{a}}$ & $89^{c}$ & $62^{\mathrm{a}}$ & $64^{\circ}$ \\
\hline 6 & $25 \mathrm{~min}$ & $8 \mathrm{~h}$ & $93-95^{\mathrm{a}}$ & $91^{\mathrm{c}}$ & $80^{\mathrm{a}}$ & $77^{\mathrm{C}}$ \\
\hline 7 & $20 \mathrm{~min}$ & $4 \mathrm{~h}$ & $90-92^{b}$ & $88^{c}$ & $66^{\mathrm{b}}$ & $64^{\circ}$ \\
\hline 8 & $15 \mathrm{~min}$ & $4 \mathrm{~h}$ & $84-86^{b}$ & $88^{c}$ & $58^{\mathrm{b}}$ & $55^{\mathrm{c}}$ \\
\hline 9 & $20 \mathrm{~min}$ & $4 \mathrm{~h}$ & $90-92^{b}$ & $88^{c}$ & $63^{\mathrm{b}}$ & $66^{\mathrm{c}}$ \\
\hline 10 & $20 \mathrm{~min}$ & $6 \mathrm{~h}$ & $92-94^{a}$ & $92^{\mathrm{c}}$ & $85^{\mathrm{a}}$ & $82^{\circ}$ \\
\hline 11 & $20 \mathrm{~min}$ & $6 \mathrm{~h}$ & $88^{\mathrm{a}}$ & $85^{c}$ & $76^{\mathrm{a}}$ & $73^{\circ}$ \\
\hline 12 & $15 \mathrm{~min}$ & $4 \mathrm{~h}$ & $91-92^{b}$ & $90^{c}$ & $63^{\mathrm{b}}$ & $59^{\circ}$ \\
\hline 13 & $15 \mathrm{~min}$ & $4 \mathrm{~h}$ & $86-88^{b}$ & $85^{\mathrm{c}}$ & $69^{\mathrm{b}}$ & $66^{\mathrm{c}}$ \\
\hline 14 & $20 \mathrm{~min}$ & $4 \mathrm{~h}$ & $82^{\mathrm{b}}$ & $84^{c}$ & $80^{\mathrm{b}}$ & $76^{\mathrm{c}}$ \\
\hline 15 & $15 \mathrm{~min}$ & $6 \mathrm{~h}$ & $75-77^{\mathrm{b}}$ & $80^{c}$ & $56^{\mathrm{b}}$ & $50^{\circ}$ \\
\hline 16 & $20 \mathrm{~min}$ & $6 \mathrm{~h}$ & $79^{\mathrm{b}}$ & $82^{c}$ & $57^{\mathrm{b}}$ & $50^{\circ}$ \\
\hline
\end{tabular}

${ }^{*}$ Micro. Irr.; microwave irradiation, Conv. H.; conventional heating. ${ }^{\mathrm{a}}$ piperidine in ethanol, ${ }^{\mathrm{b}}$ sodium carbonate in diphenyl ether, ${ }^{\mathrm{c}}$ chitosan in dioxane (green medium). 
Table 2. Diameters of inhibition zones (mm) of newly synthesized compounds against different test bacteria and fungi on nutrient agar at $30^{\circ} \mathrm{C}$ after 24 .

\begin{tabular}{|c|c|c|c|c|c|c|c|c|c|}
\hline $\begin{array}{c}\text { Comp. } \\
\text { no. }\end{array}$ & $\begin{array}{l}\text { Candida } \\
\text { albicans }\end{array}$ & $\begin{array}{c}\text { Staphylococcus } \\
\text { aures }\end{array}$ & Citrobacter & $\begin{array}{l}\text { Bacillus } \\
\text { subtilus }\end{array}$ & $\begin{array}{l}\text { Bacillus } \\
\text { cereus }\end{array}$ & Klibsella & Serratia & E. coli & $\begin{array}{c}\text { Pseudomonas } \\
\text { vulgarus }\end{array}$ \\
\hline 7 & 10 & - ve & - ve & 5 & - ve & 7 & 11 & -ve & - ve \\
\hline 8 & 8 & -ve & 8 & - ve & 11 & -ve & 9 & -ve & 8 \\
\hline 9 & 15 & 13 & 15 & 20 & 19 & 20 & 17 & 20 & 9 \\
\hline 12 & 14 & - ve & - ve & 14 & 13 & 15 & - ve & - ve & - ve \\
\hline 13 & 17 & - ve & - ve & 12 & 18 & 17 & 22 & 9 & - ve \\
\hline 14 & 20 & - ve & 12 & 15 & 20 & 10 & 17 & -ve & - ve \\
\hline 15 & 27 & - ve & - ve & 16 & 15 & 6 & 14 & 19 & - ve \\
\hline 16 & 30 & 17 & 16 & - ve & 24 & 19 & 16 & 10 & 16 \\
\hline Amoxycillin & - ve & - ve & - ve & - ve & - ve & -ve & 12 & - ve & 10 \\
\hline Chlormphe-nicol & 21 & 18 & 10 & 16 & 17 & -ve & 25 & 20 & - ve \\
\hline Tetracycline & 10 & 18 & -ve & -ve & 14 & 10 & -ve & 18 & -ve \\
\hline
\end{tabular}

The sensitivity of microorganisms to the tested compounds is identified in the following manner * : Highly sensitive = Inhibition zone: 15 - 20 mm; moderately sensitive = Inhibition zone: 10 - $15 \mathrm{~mm}$; slightly sensitive = Inhibition zone: 1 - $10 \mathrm{~mm}$; Not sensitive = Inhibition zone: 0 mm; ${ }^{*}$ each result represents the average of triplicate readings.

Table 3. Minimal inhibitory concentration (MIC) of the provided samples against test microorganisms (MIC) $\mu \mathrm{g} / \mathrm{ml}$.

\begin{tabular}{ccccccccc}
\hline $\begin{array}{c}\text { Comp. } \\
\text { no. }\end{array}$ & $\begin{array}{c}\text { Candida } \\
\text { albicans }\end{array}$ & $\begin{array}{c}\text { Staphylo } \\
\text { coccusaures }\end{array}$ & Citrobacter & $\begin{array}{c}\text { Bacillus } \\
\text { subtilus }\end{array}$ & $\begin{array}{c}\text { Bacillus } \\
\text { cereus }\end{array}$ & Klibsella & $\begin{array}{c}\text { Serratia } \\
\text { E. coli }\end{array} \begin{array}{c}\text { Pseudonas } \\
\text { vulgarus }\end{array}$ \\
\hline $\mathbf{9}$ & 250 & 180 & 250 & 500 & 250 & 500 & 1000 & 250 \\
$\mathbf{1 6}$ & 250 & 500 & 1000 & 1000 & 180 & 500 & 1000 & 500 \\
Chlorm-phenicol & 31.25 & 62.5 & 62.5 & 31.25 & 31.25 & - & 31.25 & 62.5 \\
\hline
\end{tabular}

All the dilutions of both samples and standards were performed by double fold dilution.

\subsubsection{Antioxidant Screening}

Since antioxidants are gaining attention as a potential means of treating a large number of life style diseases like cancer, it is immense significance via a convenient synthetic methodology. The DPPH radical has been widely used to the ability of compounds to behave as been radical scavengers or hydrogen donors. Briefly the assay measures the decrease in absorbance of the DPPH radicals at a characteristic wave length after 60 min incubation of the DPPH radical with different concentrations (from $5 \mu \mathrm{g} / \mathrm{ml}$ to $50 \mu \mathrm{g} / \mathrm{ml}$ ) of the antioxidant compounds according to the method of Brand-Williams et al. [19]. The absorbance of the reaction mixture was recorded by bcc using a UV visible spectrometer (Genway 6305). L-ascorbic acid (vitamin C) was used as standard antioxidant (positive control). Results are expressed as the percentage of the DPPH free radical scavenging at (five concentrations), each value is expressed as the average of three experiments per concentration \pm SD.

Radical of the tested measured and the results were depicted in (Table 4) and (Figure 1). From DPPH method the range of IC $_{50}$ for compounds (2-16) is from $3.2-6.6 \mu \mathrm{g} / \mathrm{ml}$. The highest IC S0 $_{50}(6.6 \mu \mathrm{g} / \mathrm{ml})$ and lowest activity showed in compound 2 . The fused furane, pyrane, imidazole, oxathiine and benzooxine rings with pyrazole ring showed decrease in $\mathrm{IC}_{50}(4.1$ - 5.5) and increase in antioxidant activity. The fused pyrazole ring with thiazole, thiazolopyrimidine and quinoxaline rings showed more decrease in $\mathrm{IC}_{50}(3.3$ - 3.6) and more increase in antioxidant activity. Thiazine carboxylic acid fused with pyrazole ring 12 showed much closed antioxidant reactivity $\mathrm{IC}_{50}(3.2 \mu \mathrm{g} / \mathrm{ml})$ compared with standard ascorbic acid due to the free carboxylic group in thiazine ring. 
Table 4. Percentage of free radical scavenging activity (DPPH radical) obtained for the tested compounds.

\begin{tabular}{cll}
\hline Comp. No. & IC $\mathbf{5 0}(\boldsymbol{\mu g} / \mathbf{m l})$ \\
\hline 2 & 6.6 \\
3 & 4.2 \\
4 & 5.4 \\
5 & 5.2 \\
6 & 5.5 \\
7 & 5.1 \\
8 & 5.0 \\
9 & 3.6 \\
10 & 4.5 \\
11 & 3.4 \\
12 & 3.2 \\
13 & 4.6 \\
14 & 4.2 \\
15 & 4.1 \\
16 & 3.3 \\
Ascorbic acid & 3.2 \\
\hline & & 3.2 \\
\hline
\end{tabular}

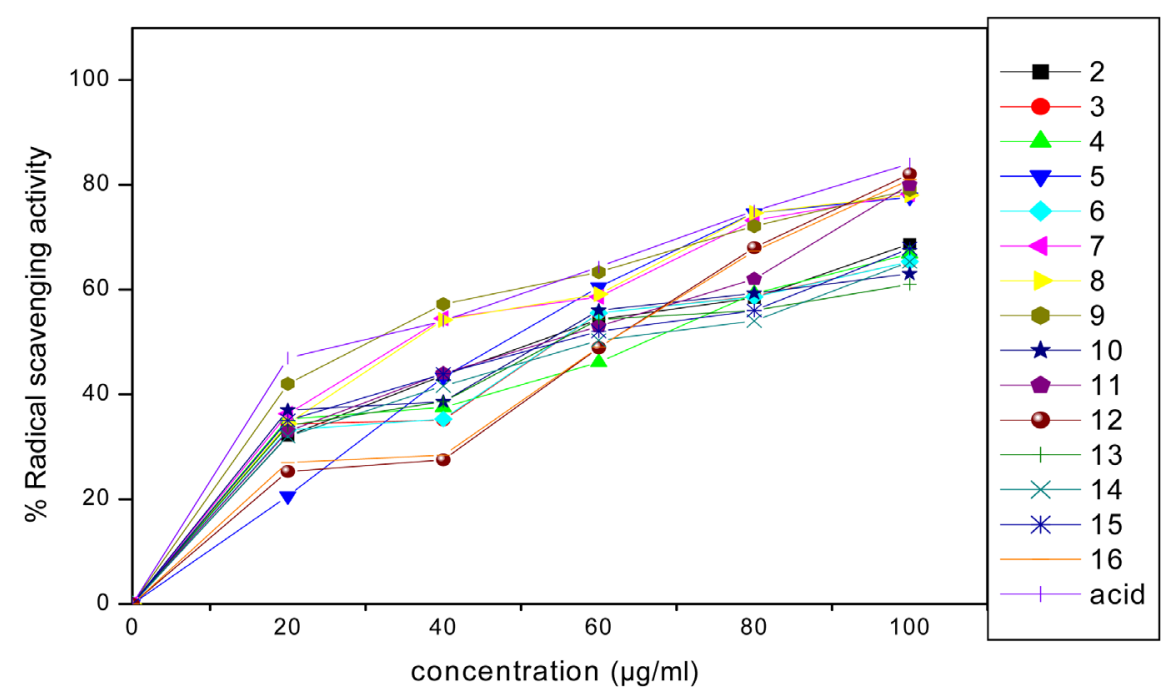

Figure 1. Scavenging antioxidant percentage of the tested compounds.

\section{Conclusion}

In the present work we could manage to report a new, simple eco-friendly technique for the synthesis of heterocyclic moieties fused with pyrazole system. The antimicrobial screening and antioxidant activity of some synthesized compounds have shown promising activities.

\section{References}

[1] Tejedor, D. and Garcia-Tellador, F. (2007) Chemo-Differentiating ABB' Multicomponent Reactions. Privileged Building Blocks. Chemical Society Reviews, 36, 484-491. http://dx.doi.org/10.1039/B608164A 
[2] Weber, L. (2002) Multi-Component Reactions and Evolutionary Chemistry. Drug Discovery Today, 7, 143-147. http://dx.doi.org/10.1016/S1359-6446(02)00010-7

[3] Hulme, C. and Gore, V. (2003) Multi-component Reactions: Emerging Chemistry in Drug Discovery from Xylocain to Crixivan. Current Medicinal Chemistry, 10, 51-80. http://dx.doi.org/10.2174/0929867033368600

[4] Rizk, H.F., EI-Badawi, M.A., Ibrahim, S.A. and El-Borai, M.A. (2011) Cyclization of 4,5-Diamino Pyrazole Derivatives and Their Antibacterial Activities. Chinese Journal of Chemistry, 29, 1451-1459. http://dx.doi.org/10.1002/cjoc.201180265

[5] Yang, B., Lu, Y., Chen, C.-J., Cui, J.-P. and Cai, M.-S. (2009) The Synthesis of 5-Amino-4-arylazo-3-methyl-1H-pyrazoles and 5-Aryl-3-methylpyrazole[3,4-e][1,2,3,4]tetrazines. Dyes and Pigments, 83, 144-147. http://dx.doi.org/10.1016/j.dyepig.2008.12.011

[6] Tsai, P.C. and Wang, I.J. (2005) Synthesis and Solvatochromic Properties of Some Disazo Dyes Derived from Pyrazolo [1,5-a]pyrimidine Derivatives. Dyes and Pigments, 64, 259-264. http://dx.doi.org/10.1016/j.dyepig.2004.05.013

[7] Kumar, V., Aggarwal, R., Tyagi, P. and Singh, S. (2005), Synthesis and Antibacterial Activity of Some New 1-Heteroaryl-5-amino-4-phenyl-3-trifluoromethylpyrazoles. European Journal of Medicinal Chemistry, 40, 922-927. http://dx.doi.org/10.1016/j.ejmech.2005.03.021

[8] Yang, B., Lu, Y., Chen, C., Cui, J. and Cai, M. (2009) The Synthesis of 5-Amino-4-arylazo-3-methyl-1H-pyrazoles and 5-aryl-3-methylpyrazole[3,4-e][1,2,3,4]tetrazines. Dyes and Pigments, 83, 144-147.

http://dx.doi.org/10.1016/j.dyepig.2008.12.011

[9] Gudmundsson, K.S., Johns, B.A., Wang, Z., Turner, E.M., Allen, S.H., Freeman, G.A., Lesleboyd, F., Sexton, C.D., Sellseth, D.W., Moniri, K.R. and Greeh., K.L. (2005) Synthesis of Novel Substituted 2-Phenylpyrazolopyridines with Potent Activity against Herpesviruses. Bioorganic \& Medicinal Chemistry, 13, 5346-5361. http://dx.doi.org/10.1016/j.bmc.2005.05.043

[10] Hwang, S.H., Wagner, K.M., Morisseau, C., Liu, J.-Y., Dong, H., Wecksler, A.T. and Hammock, B.D. (2011) Synthesis and Structure-Activity Relationship Studies of Urea-Containing Pyrazoles as Dual Inhibitors of Cyclooxygenase-2 and Soluble Epoxide Hydrolase. Journal of Medicinal Chemistry, 54, 3037-3050. http://dx.doi.org/10.1021/jm2001376

[11] Szabó, G., Fischer, J., Kis-Varga, Á. and Gyires, K. (2008) New Celecoxib Derivatives as Anti-Inflammatory Agents. Journal of Medicinal Chemistry, 51, 142-147. http://dx.doi.org/10.1021/jm070821f

[12] Chimichi, S., Boccalini, M., Hassan, M.M., Viola, G., Dall Ácqua, F. and Curini, M. (2006) Synthesis, Structural Determination and Photo-Antiproliferative Activity of New 3-Pyrazolyl or -Isoxazolyl Substituted 4-Hydroxy-2(1H)quinolinones. Tetrahedron, 62, 90-96. http://dx.doi.org/10.1016/j.tet.2005.09.135

[13] Rizk, H.F., EI-Badawi, M.A., Ibrahim, S.A. and El-Borai, M.A. (2011) Synthesis of Some Novel Heterocyclic Dyes Derived from Pyrazole Derivatives. Arabian Journal of Chemistry, 4, 37-44. http://dx.doi.org/10.1016/j.arabjc.2010.06.012

[14] El-Borai, M.A., Rizk, H.F., Abd-Aal, M.F. and El-Deeb, I.Y. (2012) Synthesis of Pyrazolo[3,4-b]pyridines under Microwave Irradiation in Multi-Component Reactions and Their Antitumor and Antimicrobial Activities-Part 1. European Journal of Medicinal Chemistry, 48, 92-96. http://dx.doi.org/10.1016/j.ejmech.2011.11.038

[15] El-Borai, M.A., Rizk, H.F., Beltagy, D.M. and El-Deeb, I.Y. (2013) Microwave-Assisted Synthesis of Some New Pyrazolopyridines and Their Antioxidant, Antitumor and Antimicrobial Activities. European Journal of Medicinal Chemistry, 66, 415-422. http://dx.doi.org/10.1016/j.ejmech.2013.04.043

[16] El-Borai, M.A., Rizk, H.F., El-Deeb, I.Y. and Sadek, M.E. (2014) A Convenient Synthesis of a Series of Pyrazolo [3,4-D]pyrimidines as Potential Antimicrobial and Antioxidant Agents. Journal of Applied Chemistry, 3, 1526-1537.

[17] Pridham, T.G., Lindenfelser, L.A., Shotwell, O.L., Stodola, F., Benedict, R.G., Foley, C., Jacks, P.W., Zaumeyer, W.J., Perston, W.H. and Mitchell, J.W. (1956) Phytopathology, 46, 27.

[18] Skehan, P., Storeng, R., Scudiero, D., Monks, A., Mc Mahon, J., Vistica, D., Warren, J.T., Bokesch, H., Kenney, S. and Boyd, M.R. (1990) New Colorimetric Cytotoxicity Assay for Anticancer-Drug Screening. Journal of the National Cancer Institute, 82, 1107-1112. http://dx.doi.org/10.1093/jnci/82.13.1107

[19] Williams, W.B., Cuvelier, M.E., Berset, C. and Lebensm,W. (1995) Use of a Free Radical Method to Evaluate Antioxidant Activity. LWT-Food Science and Technology, 28, 25-30. http://dx.doi.org/10.1016/S0023-6438(95)80008-5

[20] Boger, D.L. and Nakahara, S. (1991) Diels-Alder Reactions of N-Sulfonyl-1-Aza-1,3-Butadienes: Development of a Synthetic approach to the Streptonigrone C Ring. Journal of Organic Chemistry, 56, 880-884. http://dx.doi.org/10.1021/jo00002a077

[21] Zhang, T.Y., Stout, J.R., Keay, J.G., Scriven, E.F.V., Toomey, J.E. and Goe, G.L. (1995) Regioselective Synthesis of 2-Chloro-3-Pyridinecarboxylates. Tetrahedron, 51, 13177-13184. http://dx.doi.org/10.1016/0040-4020(95)00788-A 
[22] Ma, X. and Gang, D.R. (2004) The Lycopodium Alkaloids. Natural Product Reports, 21, 752-772. http://dx.doi.org/10.1039/b409720n

[23] George, R. and Thomas, H. (1934) The Synthesis of Pyridylpyrazoles. Journal of the Chemical Society (Resumed), 1739-1741. 